\title{
PENGARUH INTRUSI TERHADAP LAPISAN BATUBARA E (KELADI) FORMASI MUARA ENIM, SUB-CEKUNGAN PALEMBANG SELATAN, SUMATERA SELATAN
}

\author{
The Influence of Intrusion on Coal Seam E (Keladi) of Muara Enim \\ Formation, South Palembang Sub-basin, South Sumatera
}

\author{
ASEP B. PURNAMA \\ Puslitbang Teknologi Mineral dan Batubara \\ Jalan Jenderal Sudirman No. 623 Bandung 40211 \\ Telp. (022) 6030483, Fax. (022) 6003373 \\ e-mail: asep.purnama@esdm.go.id
}

\begin{abstract}
ABSTRAK
Penelitian ini dilakukan untuk mengetahui karakteristik Lapisan Batubara E dan pengaruh struktur geologi/intrusi batuan beku terhadap parameter kualitas lapisan batubara tersebut di Sub-cekungan Palembang Selatan. Informasi mengenai karakteristik kualitas lapisan batubara ini masih sangat minim, karena berada jauh di bawah permukaan bumi, sehingga menyulitkan untuk diteliti secara komprehensif. Hal tersebut berbeda dengan Lapisan Batubara A1, A2, B1, B2, dan C yang sudah banyak diteliti oleh peneliti terdahulu, karena lapisan tersebut tersingkap di permukaan, sehingga mudah untuk diteliti. Penelitian ini bertujuan untuk mengorelasikan kualitas Lapisan Batubara E dengan struktur geologi. Struktur tersebut berupa sesar normal yang dilalui oleh intrusi batuan andesit berarah timurlaut/baratdaya yang mengontrol daerah penelitian. Pengamatan dilakukan terhadap percontoh batubara hasil pengeboran eksplorasi pada lubang penambangan Air Laya. Analisis yang dilakukan meliputi parameter kualitas berupa tingkat kematangan (reflektansi vitrinit) dan nilai kalor yang merupakan indikator ada tidaknya pengaruh struktur geologi (intrusi andesit) terhadap lapisan batubara tersebut. Hasil penelitian menunjukkan bahwa kualitas lapisan batubara tersebut terpengaruh oleh struktur geologi/intrusi andesit yang diinterpretasikan dari data anomali nilai reflektansi vitrinit dan nilai kalor pada masing-masing percontoh. Hasil analisis pada percontoh BAL 03 diperoleh nilai $\mathrm{RV}_{\max }=0,63 \%$ dan nilai kalor $=8.345 \mathrm{kkal} / \mathrm{kg}$ dengan kategori batubara sub-bituminus; pada percontoh BAL 07 didapatkan nilai $R v_{\max }=0,78 \%$ dan nilai kalor $=8.315 \mathrm{kkal} / \mathrm{kg}$ dengan kategori batubara bituminus yang mengandung zat terbang tinggi, sedangkan pada percontoh lubang bor BAL 02 didapat nilai RVmax $=0,45 \%$ dan nilai $\mathrm{kalor}=6.836 \mathrm{kkal} / \mathrm{kg}$, percontoh $\mathrm{BAL} 04$ didapatkan nilai $\mathrm{RVmax}=0,43 \%$ dan nilai $\mathrm{kalor}=$ $6.775 \mathrm{kkal} / \mathrm{kg}$, percontoh BAL 05 didapatkan nilai $\mathrm{RV \operatorname {max }}=0,46 \%$ dan nilai $\mathrm{kalor}=7.115 \mathrm{kkal} / \mathrm{kg}$, percontoh $\mathrm{BAL}$ 06 didapatkan nilai $R v_{\max }=0,47 \%$ dan nilai kalor $=6.950 \mathrm{kkal} / \mathrm{kg}$. Semuanya masuk dalam kategori batubara subbituminus. Dapat disimpulkan bahwa percontoh di lokasi BAL 03 dan BAL 07 terpengaruh oleh struktur geologi (intrusi andesit), sedangkan percontoh di lokasi BAL 02, BAL 04, BAL 05, dan BAL 06 tidak terpengaruh. Interpretasi tersebut didukung dengan terdapatnya tiga rentang nilai reflektansi vitrinit (RVmax) pada Lapisan Batubara $\mathrm{E}$, yaitu $0,4-0,5 \%, 0,58-0,66$ dan $0,74-0,82 \%$.
\end{abstract}

Kata kunci: struktur geologi, peringkat batubara, kualitas, Lapisan Batubara E, Sub-cekungan Palembang Selatan

\begin{abstract}
This study was conducted to determine the characteristics of the E coal seam and the influence of geological structure/igneous rock intrusion on the quality parameters of the coal. Information on characteristics such as the quality of the coal is still very limited, because it is far below the surface, making it difficult to examine
\end{abstract}


comprehensively. This condition is very different with the coal seams A1, A2, B1, B2, and C, which have been widely studied by previous researchers, because these coals have outcrops that expose on the surface, and so it is easy to examine. This study aims to correlate the quality of the coal seam $E$ with the geological structure in the form of a normal fault traversed by the andesite intrusion trend to northeast-southwest that controls the regional structure geology in the studied area. Observations were made on the coal samples from exploratory drilling at the Air Laya mining pit. The analysis includes quality parameters in terms of maturity (vitrinite reflectance) and calorific value, which are indicators of the presence or absence of geological structure (andesite intrusion) effect on the coal. The study results shows that the quality of the coal seam was affected by the geological structure/andesite intrusion, which was interpreted from the anomaly data of the vitrinite reflectance and calorific value in each sample. The analysis results obtained from the BAL 03 sample are the followings: $R v_{\max }=0.63 \%$ and calorific value $=8,345 \mathrm{kcal} / \mathrm{kg}$ as subbituminous, in the $B A L 07$ sample, $R v_{\max }=0.78 \%$ and calorific value $=8,315 \mathrm{kcal} / \mathrm{kg}$ as high volatile bituminous, meanwhile in BAL 02 sample $R v_{\max }=0.45 \%$ and calorific value $=6,836 \mathrm{kcal} / \mathrm{kg}$, $B A L 04$ sample $R v_{\max }=0.43 \%$ and calorivic value $=6,775 \mathrm{kcal} / \mathrm{kg}, B A L 05$ sample Rvmax $=0.46 \%$ and calorific value $=7,115 \mathrm{kcal} / \mathrm{kg}, B A L 06$ sample $R v_{\max }=0.47 \%$ and calorivic value $=6,950 \mathrm{kcal} / \mathrm{kg}$, all of those sample are subbituminous. It is concluded that the samples at BALs 03 and 07 were affected by geological structures (andesite intrusion), while in the samples at locations BALs 02, 04, 05, and 06 were not affected. This interpretation is supported by the presence of three ranges of vitrinite reflectance values ( $\left.R v_{\max }\right)$ in the coal, which are $0.4-0.5 \%$, $0.58-0.66$ and $0.74-0.82 \%$.

Keywords: geological structure, coal rank, quality, coal seam E, South Palembang Subbasin

\section{PENDAHULUAN}

Hampir seluruh batubara Neogen di Indonesia mempunyai kalori rendah, termasuk batubara di Cekungan Sumatera Selatan, khususnya dalam Formasi Muara Enim, berumur MiosenPliosen, kecuali di beberapa daerah yang terpengaruh intrusi batuan beku, seperti batubara di Bukit Asam (Lapangan Air Laya, Suban dan Bukit Kendi), Tanjung Enim (Susilawati dan Ward, 2006; Susilawati dkk., 2013; Santoso, 2015, 2017). Kinhill-Otto Gold (1986) dalam Salinita dan Purnama (2014) menyatakan bahwa batubara tambang Banko Barat di Tanjung Enim umumnya memiliki kandungan abu rendah dengan rata-rata $6,3 \%$ (db) dan kandungan sulfur rendah sampai sangat rendah dengan rata-rata $0,42 \%(\mathrm{db})$. Anggayana (1991) menyatakan bahwa kandungan sulfur pada batubara daerah yang terkena intrusi batuan beku sedikit lebih tinggi. Kadar abu rata-rata lapisan batubara adalah $4,95-7,88 \%$ (ar).

Daulay, Ningrum dan Cook (2000) membagi batubara Cekungan Sumatera Selatan menjadi batubara normal dan batubara terpengaruh panas. Batubara normal memiliki peringkat sub-bituminus dengan $R v_{\max } 0,40-0,50 \%$, sedangkan batubara terpengaruh panas menunjukkan peringkat bituminus sampai antrasit dengan $R v_{\max } 0,60-2,60 \%$.

Selain itu, didukung oleh peneliti lain yang menyebutkan bahwa batubara di beberapa lokasi di Tanjung Enim mempunyai nilai kalori tinggi (antrasit), seperti dinyatakan oleh Amijaya dan Littke (2006); Susilawati dan Ward (2006); Santoso (2015, 2017). Batubara bituminus yang dipengaruhi oleh pengaruh struktur geologi diketemukan juga di Kalimantan Timur, tepatnya di daerah Samarinda bagian utara dan Sangatta dengan peringkat batubara bituminus (Advanced Resources International, 2003).

Salinita dan Purnama (2014) meneliti di lokasi yang sama pada Lapisan Batubara D yang terletak sekitar $100 \mathrm{~m}$ di atas Lapisan Batubara E. Mereka menyebutkan bahwa kualitas Lapisan Batubara D dipengaruhi oleh kondisi geologi daerah tambang Air Laya. Hal tersebut diperlihatkan oleh adanya anomali nilai kalori pada lokasi BAL 01 sebesar $7.995 \mathrm{kal} / \mathrm{g}$ dan lokasi BAL $038.164 \mathrm{kal} / \mathrm{g}$ serta nilai reflektans vitrinit pada BAL 01 0,68\% dan BAL 03 0,63\%, sehingga Lapisan Batubara D termasuk ke dalam peringkat sub-bituminus dengan kandungan abu tinggi berdasarkan klasifikasi tingkat kematangan batubara dari ASTM (2009). Penelitian kali ini menganalisis pengaruh struktur geologi (intrusi) terhadap kualitas Lapisan Batubara E, dengan posisi kedalaman lapisan batubara tersebut berada 100 m di bawah Lapisan Batubara D. Daerah penelitian berada di Tambang Air Laya. Lokasi ini dapat dicapai dengan menempuh perjalanan 5 jam dari Palembang dengan menggunakan kendaraan roda empat ke arah Muara Enim (Gambar 1). 


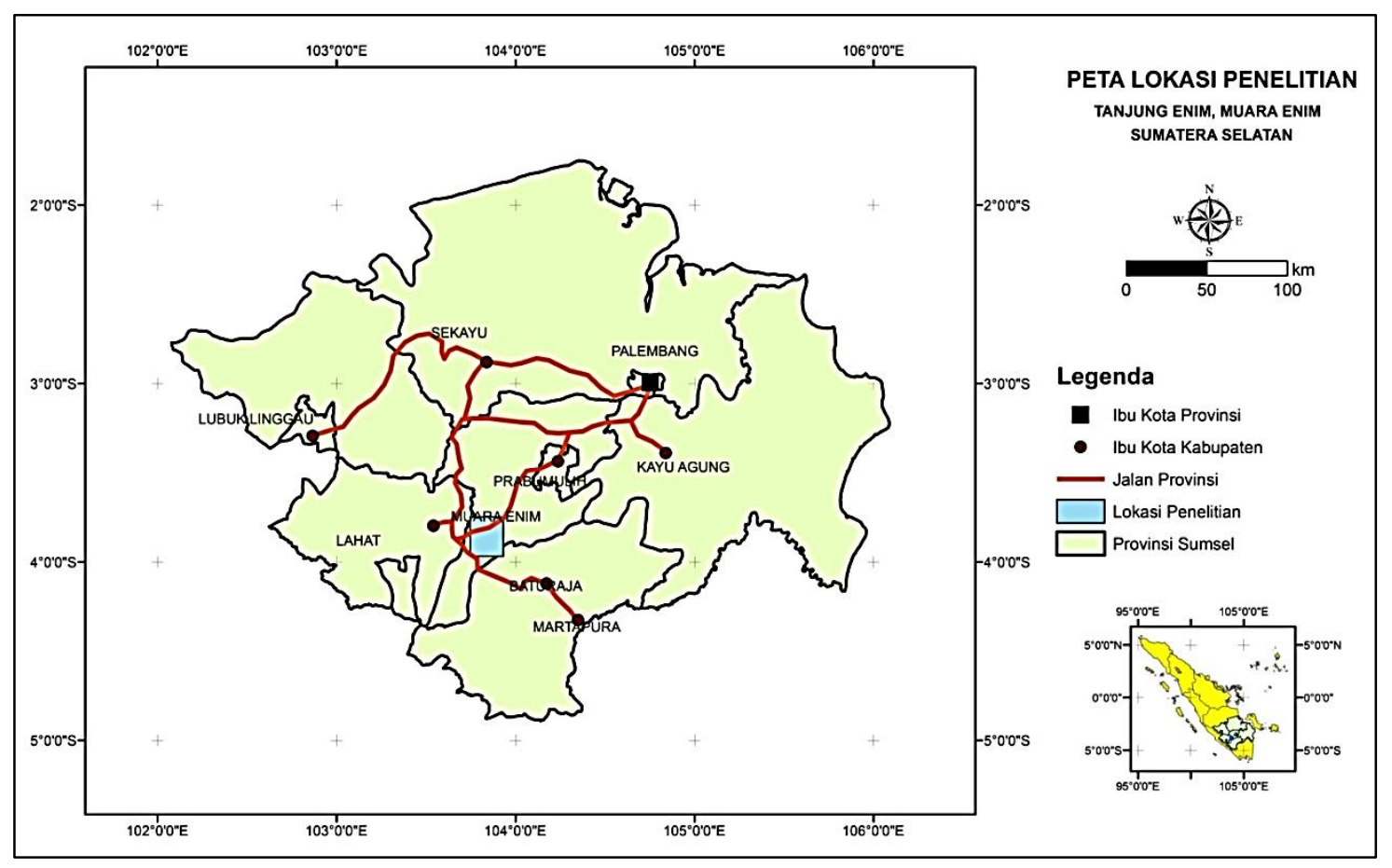

Gambar 1. Lokasi penelitian

\section{GEOLOGI REGIONAL}

Pulau Sumatera merupakan bagian dari lempeng benua Paparan Sunda. Kerak Samudera yang melandasi Samudera Hindia termasuk dalam Lempeng Indo-Pasifik, menunjam miring sepanjang Palung Sunda sebelah luar pantai barat Sumatera. Akibat penunjaman ini, terbentuk busur magmatik yang membentuk Pegunungan Bukit Barisan. Sehubungan dengan busur magmatik ini, terbentuk zona-zona seperti zona akresi, zona busur muka, dan zona busur belakang. Cekungan batubara Indonesia bagian barat berdasarkan tatanan tektoniknya dapat dibagi menjadi cekungan busur muka Neogen, cekungan antar gunung (intramontana) Paleogen, dan cekungan busur belakang Neogen (Cekungan Sumatera Tengah) (van Bemmelen, 1949; Koesoemadinata, 1978; van Gorsel, 1988). Beberapa cekungan sedimen dan/atau batubara utama di Pulau Sumatera dapat dilihat pada Gambar 2.

Cekungan Sumatera Selatan merupakan salah satu cekungan penting dalam keterdapatan endapan minyak, gas bumi dan batubara. Cekungan ini menyumbangkan sepertiga sumber daya batubara di Indonesia, dan telah mengalami tiga kali orogenesis, yakni pada umur Mesozoikum Tengah, Kapur AkhirTersier Awal, dan Plio-Plistosen (de Coster, 1974; Gafoer, Amin dan Purnomo, 2007).

Di dalam cekungan ini terdapat dua fase pengendapan, yaitu transgresi dan regresi. Fase transgresi menghasilkan endapan Kelompok Telisa yang terdiri dari Formasi-formasi: Lahat, Talang Akar, Batu Raja dan Gumai, sedangkan fase regresi menghasilkan Formasi-formasi: Air Benakat, Muara Enim dan Kasai.

Lingkungan pengendapan batubara Muara Enim terendapkan dalam lingkungan upper delta plain sampai fluvial (Permana dan Panggabean, 2011; Purnama dan Ningrum, 2012; Surjono dan Geger, 2014; Purnama, Salinita, Sudirman, Sendjaja dan Muljana, 2018).

Cekungan Sumatera Selatan menghasilkan endapan batubara dengan penyebaran yang cukup luas, namun memiliki peringkat batubara tidak terlalu tinggi, kecuali di sekitar daerah intrusi batuan beku, seperti yang terdapat di lapangan batubara Air Laya, Suban, dan Bukit Kendi (Gambar 2). 


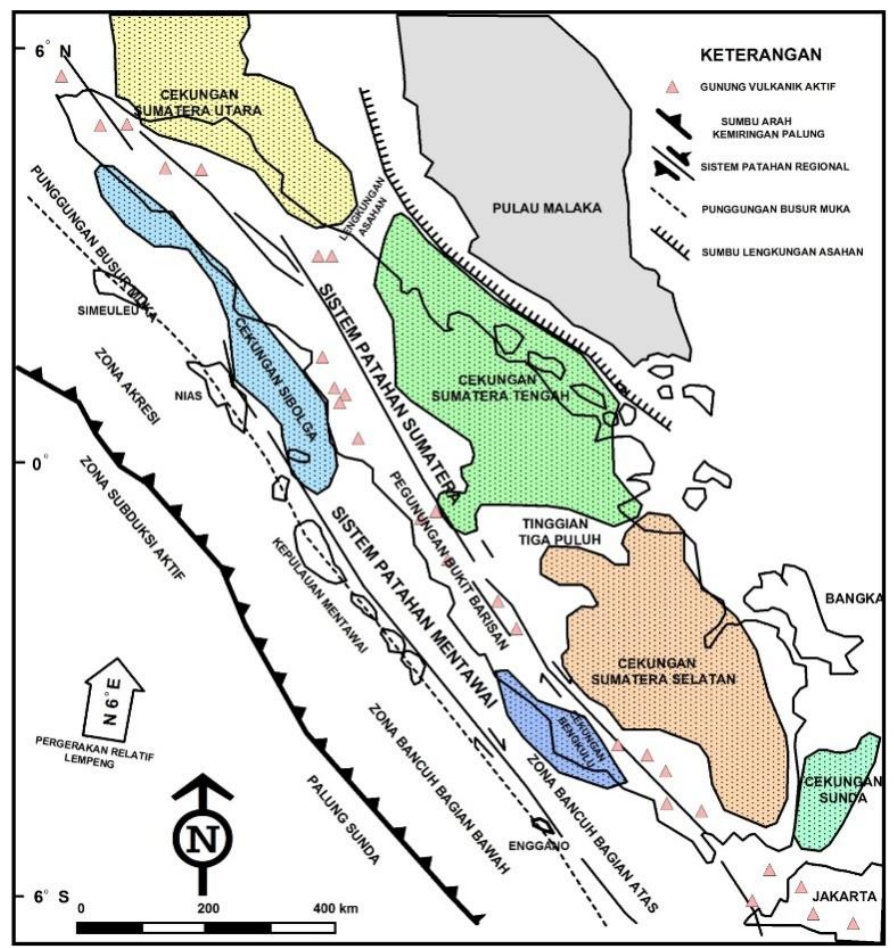

Gambar 2. Sebaran cekungan sedimen dan batubara di Pulau Sumatera (dimodifikasi dari Darman dan Sidi, 2000)

Selain Formasi Muara Enim, juga terdapat lapisan-lapisan tipis batubara pada Formasi Talang Akar dan Formasi Lahat yang berumur relatif lebih tua daripada Formasi Muara Enim. Potensi batubara berupa lapisan-lapisan tipis juga diperkirakan terdapat pada Formasi Kasai yang berumur lebih muda daripada Formasi Muara Enim.

Batubara di unit pertambangan Tanjung Enim diendapkan dalam Cekungan Sumatra Selatan, khususnya dalam Formasi Muara Enim berumur Miosen-Pliosen. Orogenesis PlioPlistosen mengakhiri pengendapan dalam cekungan ini, yang diikuti oleh adanya intrusi andesit yang berpengaruh terhadap kenaikan peringkat batubara di daerah tersebut.

Endapan batubara yang terdapat pada Formasi Muara Enim diketahui seluruhnya berjumlah \pm 21 lapisan. Namun di daerah Air Laya terdapat 7 lapisan, dengan arah umum lapisan berarah timur laut-barat daya dan kemiringan 8 - $20^{\circ}$ ke arah tenggara dan barat laut. Ketebalan batubara berkisar antara 1,34 m sampai dengan 13,04 m dengan kualitas terbagi ke dalam tiga kategori, yakni batubara uap (bituminus zat terbang tinggi), bituminus zat terbang rendah dan antrasit.

\section{Stratigrafi Regional}

Sedimentasi di Cekungan Sumatera Selatan berlangsung menerus selama Zaman Tersier disertai dengan penurunan dasar cekungan hingga ketebalan sedimen mencapai 600 meter (van Bemmelen, 1949). Siklus pengendapan di cekungan ini terbagi dalam 2 fase (Jackson, 1961), yaitu:

1. Fase transgresi, menghasilkan endapan Kelompok Telisa yang terdiri atas Formasi Lahat, Talang Akar, Baturaja dan Gumai. Kelompok Telisa ini diendapkan tidak selaras di atas batuan dasar berumur PraTersier.

2. Fase regresif, menghasilkan endapan Kelompok Palembang yang terdiri atas Formasi Air Benakat, Muara Enim dan Kasai. (Koesoemadinata, 1978) mengemukakan bahwa sedimentasi yang terjadi selama Tersier berlangsung pada lingkungan laut setengah tertutup.

Pada fase transgresi terbentuk urutan fasies darat-transisi-laut dangkal, sedangkan pada fase 
regresi terbentuk urutan sebaliknya, yaitu laut dangkal-transisi-darat. Stratigrafi cekungan Sumatera Selatan dapat dikenal satu daur besar yang terdiri atas suatu transgresi yang diikuti regresi. Endapan Tersier pada cekungan ini, dari tua ke muda terdiri atas Formasi-formasi: Lahat, Talang Akar, Baturaja, Gumai, Air Benakat.

de Coster (1974) menyimpulkan bahwa batuan dan endapan batubara yang termasuk ke dalam Formasi Muara Enim memiliki siklus pengendapan regresi.

\section{Geologi Lokal}

Lokasi penelitian berada pada areal penambangan Tambang Air Laya bagian tengah. Daerah ini terdapat intrusi batuan beku berbentuk kerucut, yang memengaruhi perubahan peringkat batubara A1, A2, B1, B2 dan C (Pujobroto, 1997) yang cenderung meningkat pada daerah yang dekat dengan area instrusi (Gambar 3 dan Gambar 4). Lapisan batubara yang ditambang di lokasi PIT
Air Laya adalah lapisan batubara A1, A2, B1, B2, dan C.

Titik elevasi pengeboran berada pada elevasi minus 60 sampai minus $80 \mathrm{~m}$ di atas permukaan laut (dpl) di PIT Air Laya atau pada lantai tambang, dengan kedalaman pengeboran antara 250 - $300 \mathrm{~m}$. Kegiatan penambangan di dareah penelitian masih aktif dan dalam tahap pengembangan, baik secara lateral maupun vertikal ke arah Lapisan Batubara D dan E.

Pada penelitian sebelumnya, Salinita dan Purnama (2014) menyebutkan bahwa posisi lapisan batubara D berada sekitar $100 \mathrm{~m}$ di bawah Lapisan Batubara C, dan kondisi penyebaran kualitasnya dipengaruhi oleh kondisi geologi daerah tambang Air Laya. Hal tersebut diperlihatkan oleh adanya anomali nilai kalori pada BAL 01 sebesar $7.995 \mathrm{kal} / \mathrm{g}$ dan BAL $038.164 \mathrm{kal} / \mathrm{g}$ serta reflektansi vitrinit pada BAL 01 0,68\% dan BAL 03 0,63\% dengan kandungan abu 2,97 - 4,92\% (adb); total sulfur $1,24-1,89 \%$ (adb).

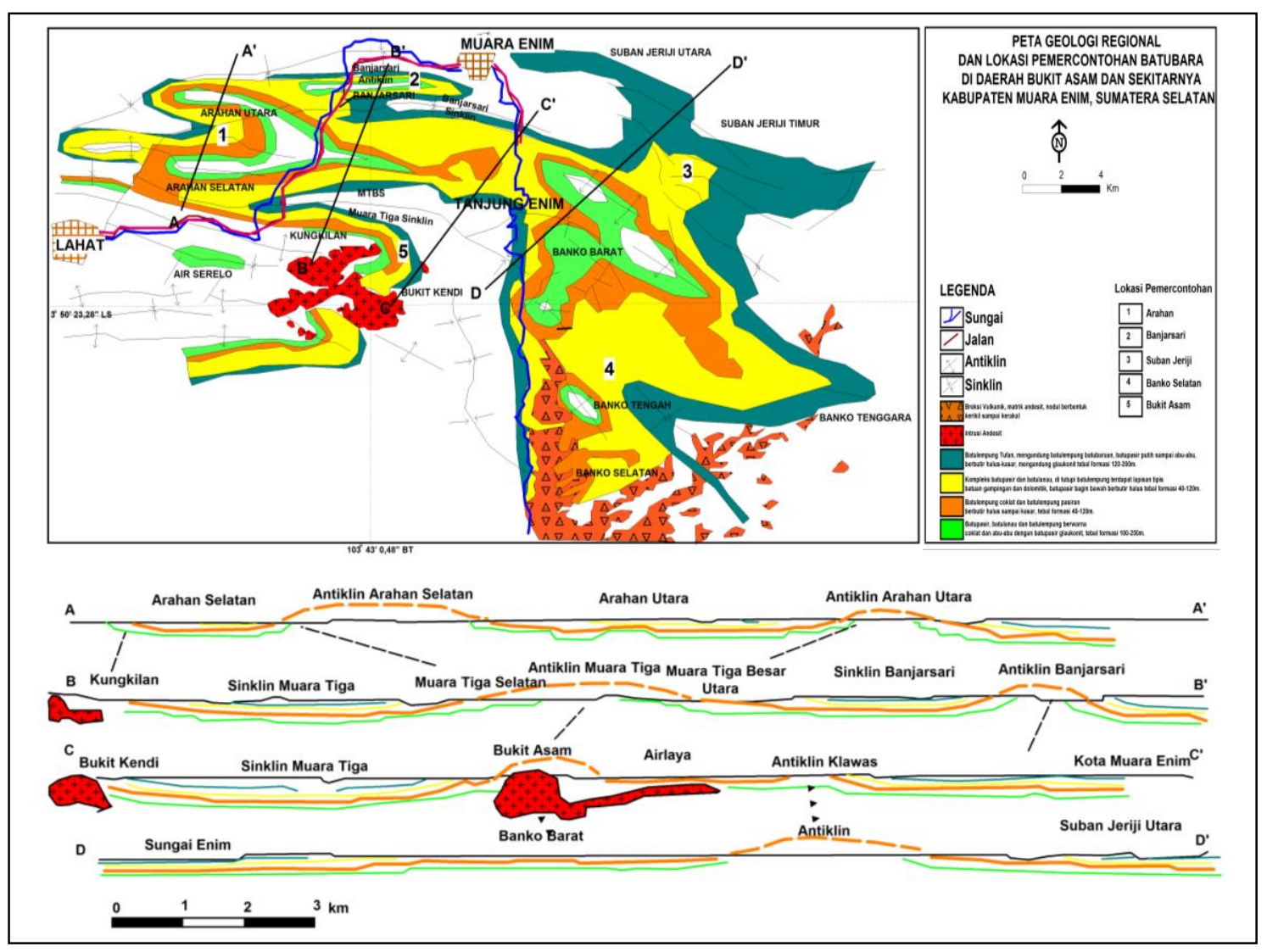

Gambar 3. Peta geologi regional lokasi penelitian (modifikasi dari Suwarna dkk. (1992); Gafoer, Amin dan Purnomo (2007); Suwarna dan Kusumahbrata (2010); Santoso (2017)) 


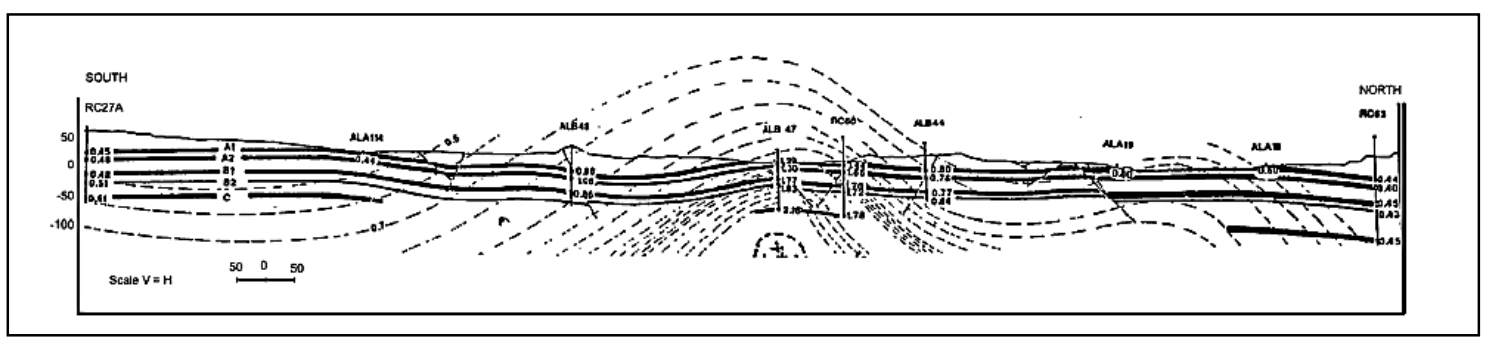

Gambar 4. Penampang sebaran batubara dan kualitas di Tambang Air Laya (Pujobroto, 1997; Pujobroto dan Hutton, 2000)

\section{METODE}

Data yang digunakan dalam menginterpretasi adanya pengaruh struktur (intrusi andesit) terhadap kualitas Lapisan Batubara E adalah data struktur geologi di lokasi penelitian, data analisis nilai reflektansi vitrinit $\left(R V_{\max }\right)$ dan nilai kalori dari percontoh lapisan batubara tersebut di titik pengeboran BAL 02, 03, 04, 05, 06 dan 07.

Kondisi struktur geologi di sekitar daerah penelitian dikontrol oleh sebaran patahan berupa sesar normal berarah timur laut-barat daya dan antiklin berarah timur laut-barat daya. Zona lemah pada sesar normal dianggap sebagai jalur intrusi andesit yang terjadi di daerah penelitian.

Percontoh batubara didapatkan dari hasil pengeboran yang dilakukan di sekitar lubang penambangan Air Laya sebanyak 7 titik. Dari 7 titik bor terdapat 6 titik yang mendapatkan Lapisan Batubara E, yaitu titik BAL 2, 3, 4, 5, 6 dan 7 (Gambar 5 dan 6). Percontoh batubara yang diperoleh direduksi ukurannya dan dibagi menjadi 2 bagian, untuk arsip dan analisis. Bagian percontoh yang akan dianalisis dibagi beberapa bagian untuk analisis proksimat, ultimat, nilai kalor, reflektansi vitrinit dan bentuk sulfur. Dari data tersebut dibuatkan korelasi secara horizontal dari masing masing titik data berupa peta iso kualitas yang diinterpretasikan.

Selain itu juga dilakukan analisis reflektansi vitrinit pada masing-masing percontoh sebanyak 30x untuk mengetahui nilai reflektansi maksimum rata-rata, sehingga dapat diketahui tingkat kematangan batubara tersebut. Analisis reflektansi vitrinit adalah analisis untuk menentukan besarnya intensitas sinar yang dipantulkan kembali oleh maseral vitrinit. Peningkatan besaran intensitas ini bersifat progresif dengan meningkatnya pembatubaraan, sehingga dapat digunakan sebagai parameter tingkat kematangan (peringkat) suatu lapisan batubara.

Pengukuran reflektansi vitrinit dilakukan di bawah minyak imersi (immersion oil) yang memiliki indeks refraksi 1,52 pada panjang gelombang $546 \mathrm{~nm}$ dan temperatur $23^{\circ} \mathrm{C}$. Untuk mendapatkan hasil pengukuran yang akurat, digunakan standar reflektansi yang diketahui. Dalam penelitian ini standar reflektansi yang dipergunakan adalah spinel sintetik dengan besaran reflektansi 0,586\%. Pengukuran standar reflektansi dilakukan sebelum pengukuran reflektansi vitrinit (Tabel 1).

Dari hasil analisis reflektansi vitrinit lapisan batubara $\mathrm{E}$ pada masing-masing lokasi bor kemudian dikelompokkan dan dibuat histrogram, sehingga didapatkan pemodelan iso reflektansi vitrinit dan iso kalori untuk mengetahui anomali perubahan kualitas yang diakibatkan oleh pengaruh intrusi.

Tabel 1. Hubungan reflektansi vitrinit dan peringkat batubara (ASTM, 2009)

\begin{tabular}{cl}
\hline Rv max (\%) & \multicolumn{1}{c}{ Peringkat Batubara } \\
\hline$<0,2$ & gambut \\
$0,2-0,35$ & brown coal/lignit \\
$0,35-0,70$ & sub-bituminus \\
$0,70-1,10$ & bituminus zat terbang tinggi \\
$1,10-1,50$ & bituminus zat terbang menengah \\
$1,50-1,90$ & bituminus zat terbang rendah \\
$1,90-2,20$ & semi-antrasit \\
$>2,20$ & antrasit \\
\hline
\end{tabular}




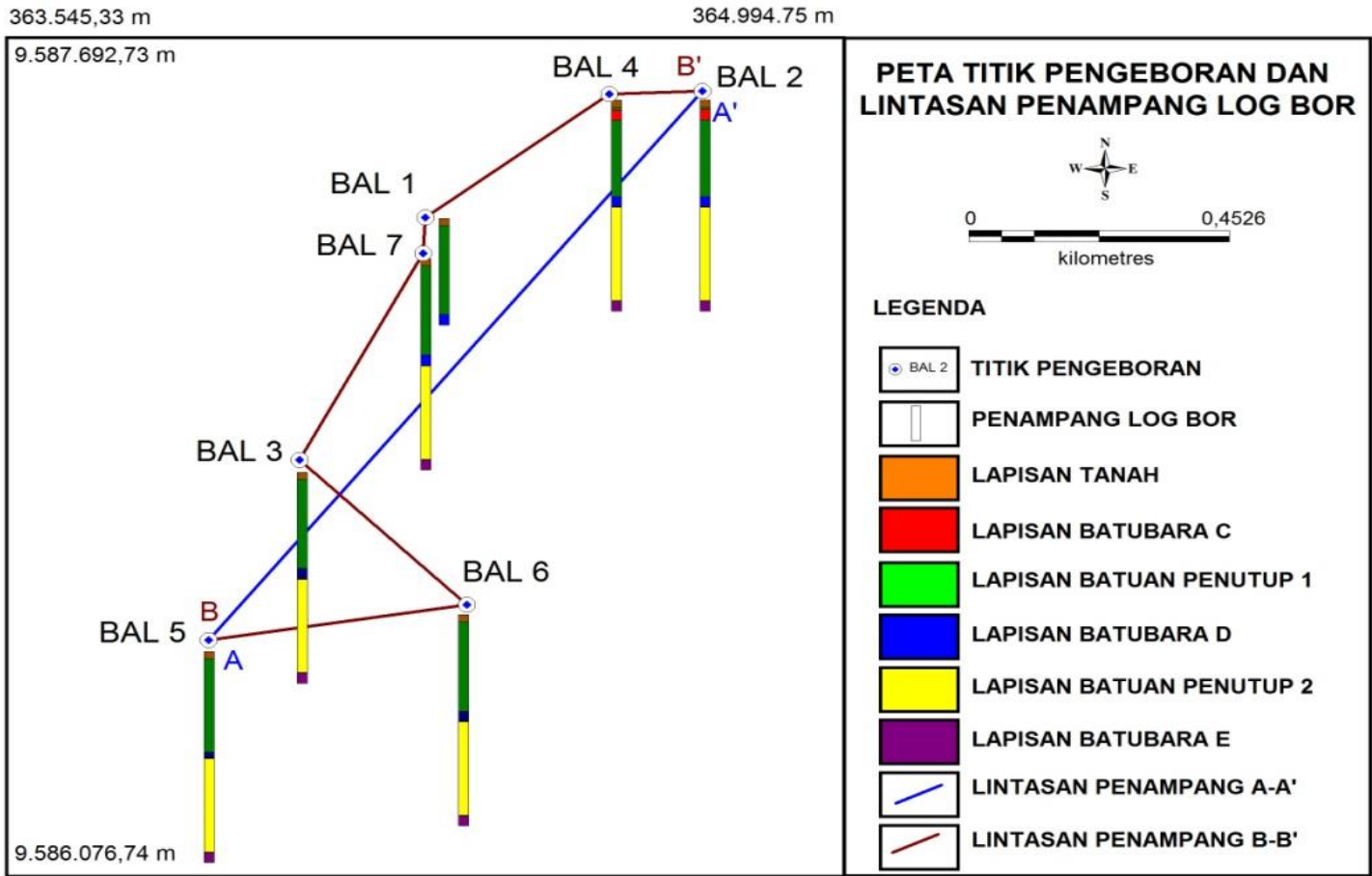

Gambar 5. Peta lokasi pengeboran dan lintasan penampang log bor

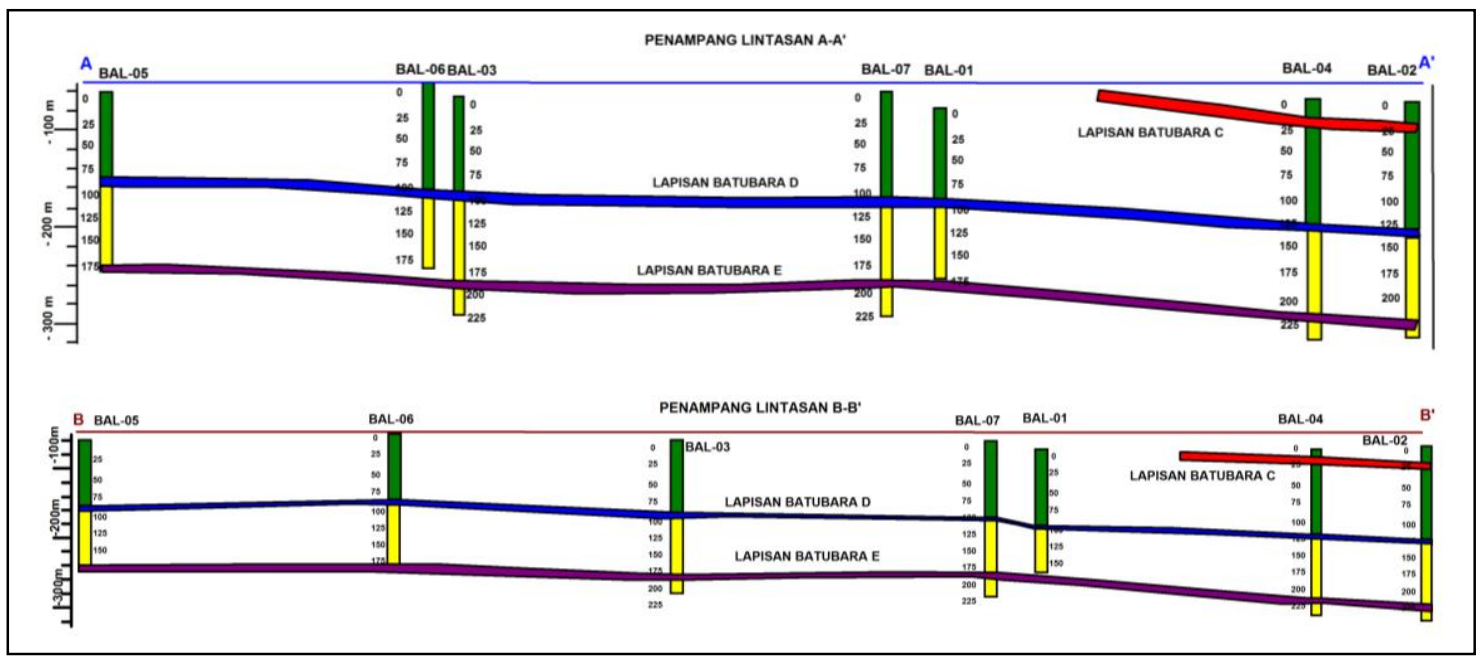

Gambar 6. Penampang log bor dan korelasi lapisan batubara

\section{HASIL DAN PEMBAHASAN}

Endapan batubara Tersier di Sumatera dan Jawa diintrusi oleh batuan beku andesit dan diorit (Darman dan Sidi, 2000; Daulay dan Santoso, 2008; Daulay dkk., 2010; Hartono, 2012).

Secara regional, di daerah ini terdapat intrusi batuan beku dengan kandungan kimia $\mathrm{SiO}_{2}$
$(58,93-59,97 \%) \mathrm{Na}_{2} \mathrm{O}(0,04-3,24 \%)$ dan $\mathrm{K}_{2} \mathrm{O}$ $(2,83-3,04 \%)$ dan termasuk ke dalam klasifikasi batuan andesit. Mineral penyusun intrusi andesit di Air Laya berupa plagioklas, kuarsa, piroksen, dan mineral lempung kaolinit (Utami $d k k_{\text {., 2016). Pengaruh intrusi tersebut }}$ menyebabkan struktur antiklin pada lapisan batuan dan lapisan batubara yang terdapat di daerah Tambang Air Laya, seperti terlihat pada Gambar 3, 4 dan 7. 
Lapisan Batubara E terdapat dalam Formasi Muara Enim yang disebandingkan dengan batubara Keladi (Amijaya dan Littke, 2006; Susilawati dan Ward, 2006; Sosrowidjojo dan Saghafi, 2009). Lokasi pengeboran percontoh lapisan batubara ini berada di daerah pertambangan batubara Air Laya. Dari korelasi antar titik bor terdapat tiga lapisan batubara, yaitu lapisan: C, D dan E dengan arah kemiringan relatif ke arah barat daya. Adapun fokus penelitian ini dilakukan pada kualitas Lapisan Batubara E yang diperbandingkan juga dengan Lapisan Batubara D, yang secara stratigrafis lebih muda dan diendapkan 100 m di atas Lapisan Batubara E.

\section{Analisis Kualitas Batubara Lapisan E}

Santoso (2017) menganalisis batubara Formasi Muara Enim mulai lapisan batubara hanging, A1, A2, B, B1, B2 dan C. Hasilnya memperlihatkan bahwa batubara yang tidak terpengaruh intrusi andesit mempunyai nilai reflektansi vitrinit antara $0,43-0,53 \%$ dan batubara yang terpengaruh intrusi andesit mempunyai nilai reflektansi vitrinit antara 0,69 - 2,60\% dan kebanyakan batubara yang mempunyai reflektansi vitrinit 0,4 - 0,5\% banyak ditemukan pada batubara di sekitar Bukit Asam.

Dari hasil analisis kualitas Lapisan Batubara E di laboratorium didapatkan data sebagai berikut: nilai kalori berkisar antara 6.836 $8.345 \mathrm{kkal} / \mathrm{kg}$ (adb); uji proksimat (nilai air lembab berkisar antara 0,92 - 11,23\% (adb), kandungan abu 1,51 - 4,94\% (adb), zat terbang 16,4 - 41,38\% (adb), karbon padat 47,52 $80,38 \%(a d b))$; total sulfur $0,6-1,6 \%(a d b)$ dan nilai reflektansi vitrinit rata-rata $0,43-0,78 \%$, termasuk ke dalam peringkat batubara subbituminus hingga bituminus zat terbang tinggi. Anomali terlihat pada percontoh BAL 03 dan percontoh BAL 07 dilihat dari nilai reflektansi rata-rata yang lebih tinggi dibandingkan dengan nilai reflektansi rata-rata percontoh yang lain (BAL 2, 4, 5 dan 6) yaitu 0.63 dan $0,78 \%$ didukung dengan data nilai kalori 8.345 dan $8.315 \mathrm{kkal} / \mathrm{kg}$; data karbon tertambat 73,85 dan 80,38\%; kandungan lengas (zat terbang) menengah 22,35 dan 16,4\%; kandungan air lembab yang rendah 0,95 dan 0,92\% (Tabel 2 dan 3).

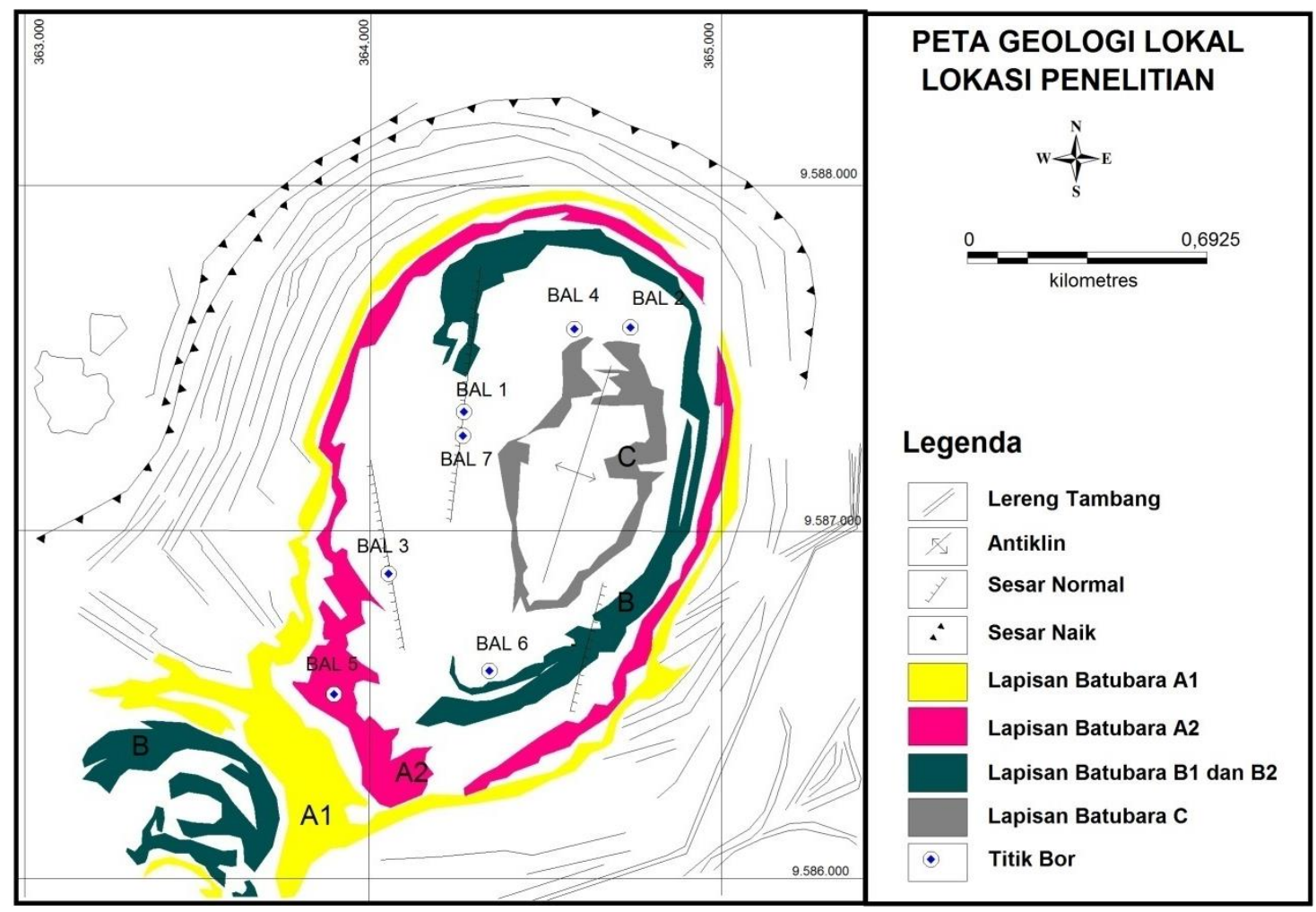

Gambar 7. Peta geologi lokal daerah penelitian 
Tabel 2. Nilai reflektansi vitrinit lapisan batubara $\mathrm{E}$

\begin{tabular}{ccccc}
\hline No & \multicolumn{2}{c}{ RVmax $(\%)$} & \multirow{2}{*}{ Jumlah Pengamatan /Pembacaan } & Peringkat \\
\cline { 2 - 3 } Percontoh & Kisaran $(\%)$ & Rata-rata $(\%)$ & & Sub-bituminus \\
BAL 02 & $0,43-0,48$ & 0,45 & $30 x$ & Sub-bituminus \\
BAL 03 & $0,58-0,66$ & 0,63 & $30 x$ & Sub-bituminus \\
BAL 04 & $0,40-0,46$ & 0,43 & $30 x$ & Sub-bituminus \\
BAL 05 & $0,44-0,48$ & 0,46 & $30 x$ & Sub-bituminus \\
BAL 06 & $0,44-0,50$ & 0,47 & $30 x$ & Bituminus dengan \\
BAL 07 & $0,75-0,82$ & 0,78 & $30 x$ & kandungan abu tinggi \\
\hline
\end{tabular}

Tabel 3. Nilai kalori dan proksimat lapisan batubara $\mathrm{E}$

\begin{tabular}{cccccc}
\hline $\begin{array}{c}\text { No } \\
\text { Percontoh }\end{array}$ & $\begin{array}{c}\text { Nilai Kalor } \\
(\text { Kkal/Kg })\end{array}$ & $\begin{array}{c}\text { Air Lembab } \\
(\% a d b)\end{array}$ & $\begin{array}{c}\text { Kandungan Abu } \\
(\% \text { adb })\end{array}$ & $\begin{array}{c}\text { Kandungan Zat terbang } \\
(\% \text { adb })\end{array}$ & $\begin{array}{c}\text { Karbon tertambat } \\
(\% \text { adb })\end{array}$ \\
\hline BAL 02 & 6.836 & 10,07 & 1,51 & 40,90 & 47,52 \\
BAL 03 & 8.345 & 0,95 & 2,85 & 22,35 & 73,85 \\
BAL 04 & 6.770 & 11,23 & 1,82 & 40,59 & 46,36 \\
BAL 05 & 7.115 & 6,81 & 4,01 & 41,38 & 47,80 \\
BAL 06 & 6.950 & 6,6 & 4,94 & 40,13 & 48,33 \\
BAL 07 & 8.315 & 0,92 & 2,30 & 16,40 & 80,38 \\
\hline
\end{tabular}

\section{Pengaruh Struktur Geologi terhadap Kualitas Batubara Lapisan E}

Kondisi geologi struktrur yang mengontrol lokasi penelitian terdiri dari beberapa jenis. Di bagian timur terdapat sumbu antiklin, sebagai indikasi adanya intrusi batuan beku, di sebelah barat melingkar ke utara terdapat sesar naik, dan di bagian tengah lokasi penelitian terdapat kelurusan sesar normal yang berada berarah relatif utara-selatan sampai timurlaut-baratdaya. Terdapatnya kompleks zona lemah berupa sesar normal, naik dan antiklin di daerah penelitian dapat dijadikan sebagai tempat masuknya intrusi batuan beku berupa andesit.

Indikator adanya pengaruh struktur terhadap lapisan batubara adalah perubahan peringkat dan nilai kalori batubara. Perubahan peringkat batubara dilihat dari nilai reflektansi vitrinit.

Pada kondisi normal, nilai reflektansi vitrinit pada satu lapisan batubara yang sama, nilainya relatif tidak ada perbedaan mencolok, namun ketika lapisan batubara terkena pengaruh faktor dari luar seperti struktur geologi atau intrusi, akan ada perubahan tingkat kematangan (reflektansi vitrinit) dan peningkatan nilai kalori yang disebabkan oleh pengaruh tekanan dan temperatur yang terjadi di sekitarnya.
Dari data nilai reflektansi vitrinit maksimum rata-rata $\left(R v_{\max }\right)$ pada Lapisan Batubara $\mathrm{E}$ didapat 3 rentang Rvmax yaitu 0,4 - 0,5\%, 0,58 - 0,66 dan 0,74 - 0,82\% (Gambar 8), sehingga diindikasikan lapisan batubara ini terpengaruh oleh struktur geologi berupa intrusi andesit yang berkembang di lokasi penelitian.

Kondisi tersebut mirip dengan kondisi reflektansi vitrinit Lapisan Batubara D, yang berada 100 m di atas Lapisan batubara E, yang mengalami perubahan nilai reflektansi vitrinit dan mempunyai 2 rentang nilai yaitu antara 0,36 $0,52 \%$ dan 0,58 - 0,72\% yang diketemukan di beberapa lokasi seperti BAL 01, BAL 03 dan BAL 07 (Salinita dan Purnama, 2014). Tingkat kematangan batubara Lapisan Batubara E lebih tinggi, jika dibandingkan dengan tingkat kematangan Lapisan Batubara D. Hal ini disebabkan oleh tingkat tekanan akibat timbunan lebih besar Lapisan Batubara E, karena berada $100 \mathrm{~m}$ lebih dalam dibandingkan dengan Lapisan Batubara D. Di daerah Sub-cekungan Palembang Selatan memiliki gradien geotermal sebesar 4,86\%100m (Panggabean dan Santy, 2012).

Kondisi perubahan nilai reflektansi vitrinit Lapisan Batubara E diikuti oleh perubahan nilai kalorinya, dengan anomali nilai kalori pada BAL 03 sebesar nilai kalori $8.345 \mathrm{kkal} / \mathrm{kg}$ dan BAL 07 sebesar $8.315 \mathrm{kkal} / \mathrm{kg}$ (Gambar 9 dan 10). 
Secara struktur geologi regional, lokasi BAL 03 dan BAL 07 searah dengan arah sesar normal yang ada di daerah penelitian berarah timur laut-barat daya, yang menjadi zona lemah untuk masuknya aliran intrusi batuan beku. Hal ini selaras dengan hasil penelitian sebelumnya pada Lapisan Batubara D yang berada $100 \mathrm{~m}$ di atas Lapisan Batubara E, dengan sebaran anomalinya pada BAL 01 dan BAL 07, hampir berarah timur laut-barat daya selaras dengan jalur sesar normal berarah timur laut-barat daya.

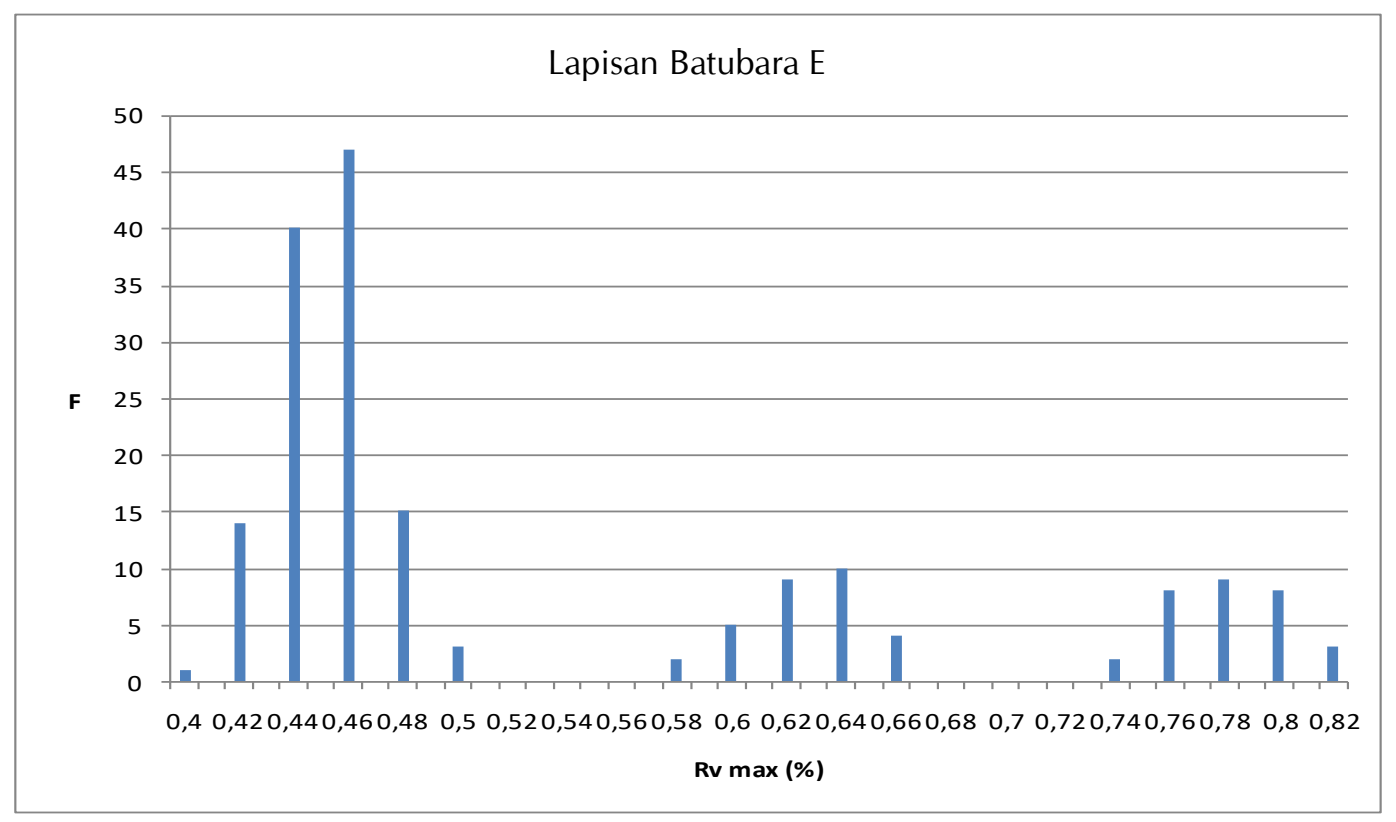

Gambar 8. Grafik rentang nilai reflektansi vitrinit lapisan batubara $\mathrm{E}$

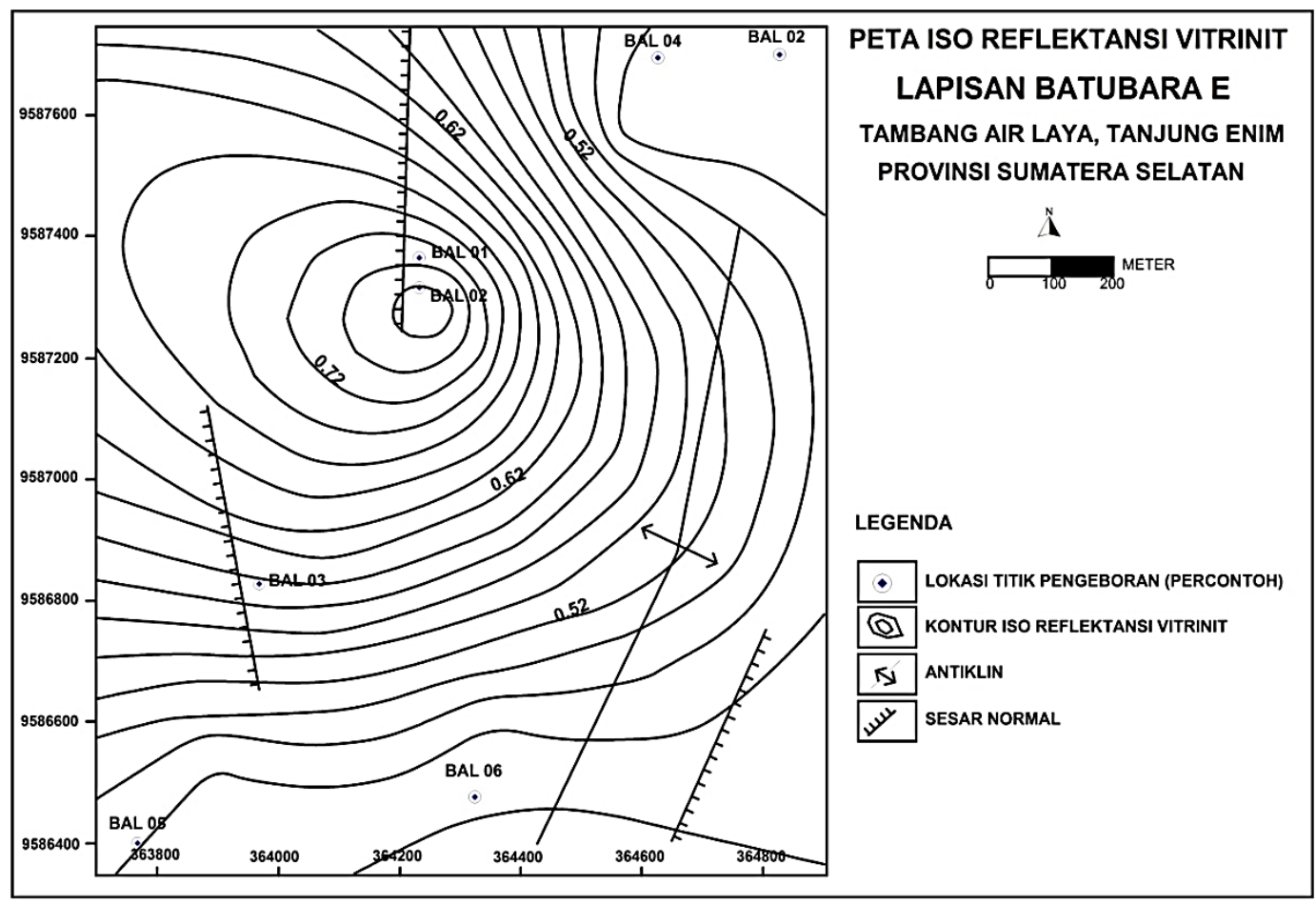

Gambar 9. Peta iso-reflektansi vitrinit maksimun rata-rata lapisan batubara E 


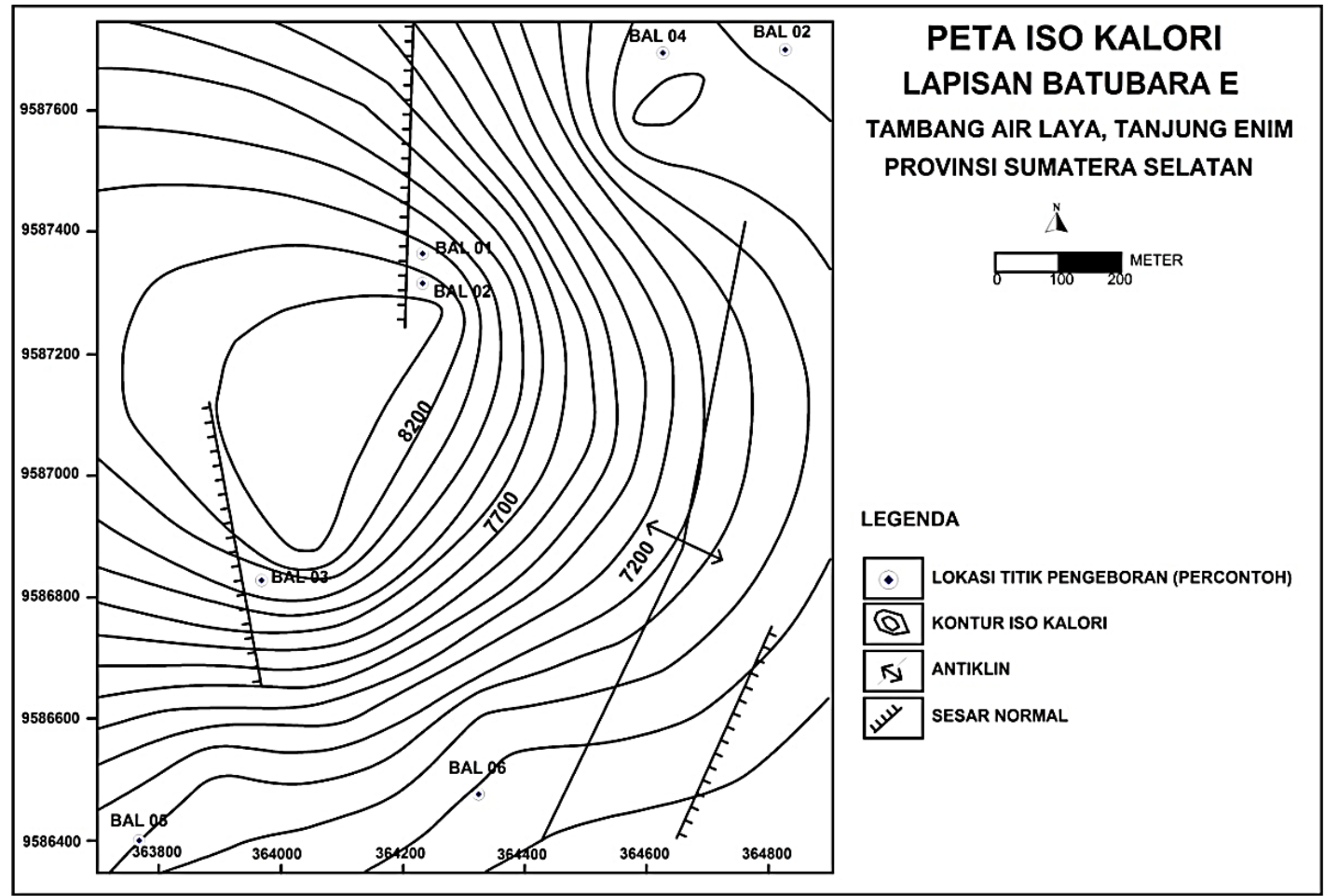

Gambar 10. Peta iso-kalori lapisan batubara E

Pada Lapisan Batubara E di Lokasi BAL 02, BAL 04, BAL 05 dan BAL 06 tidak menunjukkan peningkatan nilai Rvmax maupun nilai kalori, sehingga disimpulkan bahwa adanya peningkatan nilai reflektansi vitrinit dan nilai kalori hanya setempat-setempat tidak menyebar pada seluruh wilayah yang terkena struktur geologi (sesar normal). Karena disimpulkan bahwa kemungkinan besar aktivitas intrusi andesit yang terjadi tidak merata dan lebih berpengaruh terhadap Lapisan Batubara E yang berdekatan dengan intrusi andesit tersebut.

\section{KESIMPULAN}

Kualitas Lapisan Batubara E dipengaruhi oleh kondisi struktur geologi berupa intrusi andesit. Hal tersebut diketahui dari terdapatnya anomali nilai reflektansi vitrinit dan nilai kalor pada BAL 03 sebesar $R v_{\max }=0,63 \%$, nilai kalor $=8.345 \mathrm{kkal} / \mathrm{kg}$ yang masuk dalam kategori batubara sub-bituminus dan Bal 07 dengan $R v_{\max }=0,78 \%$, nilai kalor $=8.315 \mathrm{kkal} / \mathrm{kg}$ yang masuk dalam kategori batubara bituminus dengan kandungan zat terbang tinggi. Hal tersebut didukung juga dengan terdapatnya 3 rentang nilai reflektansi vitrinit ( $\left.R v_{\max }\right)$ pada Lapisan Batubara E, yaitu 0,4 - 0,5\%, 0,58 0,66 dan $0,74-0,82 \%$.

Terdapatnya 3 rentang R $v_{\max }$, yaitu 0,4 - 0,5\%, 0,58 - 0,66 dan 0,74 - 0,82\%, sedangkan dilokasi BAL 02, BAL 04, BAL 05 dan BAL 06, Lapisan Batubara E tidak menunjukkan adanya peningkatan nilai Rvmax maupun nilai kalori, sehingga dapat disimpulkan bahwa perubahan peringkat batubara dan nilai kalor Lapisan Batubara E hanya terjadi pada daerah yang dekat dengan jalur intrusi andesit, yaitu sesar normal berarah timur laut-barat daya.

\section{UCAPAN TERIMA KASIH}

Penulis mengucapkan terima kasih kepada Kepala Pusat Penelitian dan Pengembangan Teknologi Mineral dan Batubara yang telah memberikan dukungan penuh atas terlaksananya kegiatan penulisan ilmiah ini. Ucapan terima kasih juga kami tujukan kepada Prof. Binarko Santoso yang telah membimbing penulisan dan kepada rekan-rekan di Laboratorium Batubara yang telah membantu menganalisis batubara secara cermat. 


\section{DAFTAR PUSTAKA}

Advanced Resources International (2003) "Indonesian coalbed methane: Task 1 . Resources assessment." Virginia: Advanced Resources International, hal. 187.

Amijaya, H. dan Littke, R. (2006) "Properties of thermally metamorphosed coal from Tanjung Enim Area, South Sumatra Basin, Indonesia with special reference to the coalification path of macerals," International Journal of Coal Geology, 66(4), hal. 271-295. doi: 10.1016/j.coal.2005.07.008.

Anggayana, K. (1991) Perubahan harga parameter terukur dari pengukuran resonansi spin elektron pada batubara akibat perubahan temperatur. Institut Teknologi Bandung.

ASTM (2009) "Annual Book of ASTM Standard," in Section 5: Petroleum product, lubricants and fossil fuels (Volume 05.06 Gaseous fuel; coal and coke). ASTM International, hal. 460-481.

van Bemmelen, R. W. (1949) "General geology of Indonesia and adjacent archipelagoes," in The geology of Indonesia, Vol. 1A. Government Printing Office the Hague.

de Coster, G. L. (1974) "The geology of the Central and South Sumatera Basins," in Proceedings Indonesian Petroleum Association, 3rd Annual Convention. Jakarta: AAPG Memoir 29, hal. 189-198.

Darman, H. dan Sidi, F. H. (ed.) (2000) An outline of the geology of Indonesia. Jakarta: Indonesian Association of Geologists.

Daulay, B., Umar, D. F., Santoso, B. dan Suganal (2010) "Strategy to maximize use of coal and associated gaseous fuels in South Sumatera Basin," Indonesian Mining Journal, 13(3), hal. 119-127.

Daulay, B., Ningrum, N. S. dan Cook, A. C. (2000) "Coalification of Indonesian coal," in Proceedingsof Southeast Asian Coal Geology. Bandung, hal. 85-92.

Daulay, B. dan Santoso, B. (2008) "Characteristics of selected Sumateran tertiary coals regarding their petrographic analyses," Indonesian Mining Journal, 11(10), hal. 1-18.

Gafoer, S., Amin, T. C. dan Purnomo, J. (2007) Peta geologi lembar Lahat, Sumatera Selatan, skala 1:250.000. Bandung. van Gorsel, T. J. (1988) "Geological fieldtrip South Sumatera and Bengkulu," in South Sumatra and Bengkulu - 17th Annual Post-Convention Field Trip. Indonesian Petroleum Association.

Hartono, U. (2012) Magmatism in Kalimantan. Bandung: Centre for Geological Survey.

Jackson, A. (1961) Oil exploration: A brief review with illustrations from South Sumatra. Bandung: Institut Teknologi Bandung.

Koesoemadinata, R. P. (1978) "Sedimentary framework of Tertiary coal basins of Indonesia," in 3rd Regional Conference on Geology and Mineral Resources of SE Asia. Bangkok, hal. 621-639.

Panggabean, H. dan Santy, L. D. (2012) "Sejarah peninbunan cekungan Sumatera Selatan dan implikasinya terhadap waktu generasi hidrokarbon," Jurnal Geologi dan Sumberdaya Mineral, 22(4), hal. 225-235.

Permana, A. K. dan Panggabean, H. (2011) "Depositional environment of Sarolangun coals South Sumatera basin," Jurnal Geologi dan Sumberdaya Mineral, 21(4), hal. 225-235.

Pujobroto, A. (1997) Organic petrology and geochemistry of Bukit Asam coal, South Sumatera, Indonesia. University of Wollongong.

Pujobroto, A. dan Hutton, A. C. (2000) "Influence of andesitic intrusions on Bukit Asam coal, South Sumatra Basin Indonesia," in Proceedings of Southeast Coal Geology Conference. Bandung: Directorate General of Geology and Mineral Resources of Indonesia, hal. 81-84.

Purnama, A. B., Salinita, S., Sudirman, S., Sendjaja, Y. A. dan Muljana, B. (2018) "Penentuan lingkungan pengendapan lapisan batubara D, Formasi Muara Enim, Blok Suban Burung, Cekungan Sumatera Selatan," Jurnal Teknologi Mineral dan Batubara, 14(1), hal. 1-18. doi: 10.30556/jtmb.Vol14.No1.2018.182.

Purnama, A. B. dan Ningrum, N. S. (2012) "Petrographic characteristic and depositional environment coal Seam D (Merapi) and E (Keladi), Muara Enim Formation, South Sumatera Basin," Indonesian Mining Journal, 15(1), hal. 1-13.

Salinita, S. dan Purnama, A. B. (2014) "Pengaruh struktur geologi terhadap kualitas batubara lapisan D Formasi Muara Enim," Jurnal Teknologi Mineral dan Batubara, 10(2), hal. 91-104. 
Santoso, B. (2015) Petrologi batubara Sumatera dan Kalimantan: Jenis, peringkat dan aplikasi. Jakarta: LIPI Press.

Santoso, B. (2017) "Petrographic characteristics of selected tertiary coals from Western Indonesia according to their geological ASPECTS," Indonesian Mining Journal, 20(1), hal. 1-30. doi: 10.30556/imj.Vol20.No1.2017.178.

Sosrowidjojo, I. B. dan Saghafi, A. (2009) "Development of the first coal seam gas exploration program in Indonesia: Reservoir properties of the Muaraenim Formation, south Sumatra," International Journal of Coal Geology, 79(4), hal. 145-156. doi: 10.1016/j.coal.2009.07.002.

Surjono, S. S. dan Geger, A. (2014) "Lingkungan pengendapan dan dinamika sedimentasi Formasi Muara Enim berdasarkan litofasies di daerah Sekayu, Sumatera Selatan," dalam Prosiding Seminar Nasional Kebumian ke-7. Yogyakarta: Universitas Gadjah Mada, hal. 640-656.

Susilawati, R., Papendick, S. L., Gilcrease, P. C., Esterle, J. S., Golding, S. D. dan Mares, T. E. (2013) "Preliminary investigation of biogenic gas production in Indonesian low rank coals and implications for a renewable energy source," Journal of Asian Earth Sciences, 77, hal. 234-242.

doi: 10.1016/j.jseaes.2013.08.024.

Susilawati, R. dan Ward, C. R. (2006) "Metamorphism of mineral matter in coal from the Bukit Asam deposit, south Sumatra, Indonesia," International Journal of Coal Geology, 68(3-4), hal. 171-195. doi: 10.1016/j.coal.2006.02.003.

Suwarna, N., Suharsono, Gafoer, S., Amin, T. C., Kusnama dan Hermanto, B. (1992) "Peta geologi lembar Sorolangun, Sumatera, Skala 1:250.000." Bandung: Pusat Penelitian dan Pengembangan Geologi.

Suwarna, N. dan Kusumahbrata, Y. (2010) "Macroscopic, microscopic, and paleodepositional features of selected coals in Arahan, Banjarsari, Subanjeriji, and South Banko Regions, South Sumatra," Jurnal Geologi Indonesia, 5(4), hal. 269-290.

Utami, E. D., Raharja, R. D., Anggara, F. dan Harijoko, A. (2016) "Mineralogi dan geokimia intrusi di tambang batubara Bukit Asam, Sumatra Selatan, Indonesia," dalam Proceeding Seminar Nasional Kebumian ke-9 Peran Penelitian IImu Kebumian dalam Pemberdayaan Masyarakat. Yogyakarta: Universitas Gadjah Mada, hal. 192-198. 
